\title{
Lumen
}

Selected Proceedings from the Canadian Society for Eighteenth-Century Studies

\section{Voltaire and 'Maman': Female Sexuality, Maternity and Incest in the Tragedies}

\section{Hope M. Leith}

Volume 12, 1993

URI : https://id.erudit.org/iderudit/1012579ar

DOI : https://doi.org/10.7202/1012579ar

Aller au sommaire du numéro

Éditeur(s)

Canadian Society for Eighteenth-Century Studies / Société canadienne d'étude du dix-huitième siècle

ISSN

1209-3696 (imprimé)

1927-8284 (numérique)

Découvrir la revue

Citer cet article

Leith, H. M. (1993). Voltaire and 'Maman': Female Sexuality, Maternity and Incest in the Tragedies. Lumen, 12, 65-72. https://doi.org/10.7202/1012579ar

Copyright (c) Canadian Society for Eighteenth-Century Studies / Sociéte canadienne d'étude du dix-huitième siècle, 1993
Ce document est protégé par la loi sur le droit d'auteur. L'utilisation des services d'Érudit (y compris la reproduction) est assujettie à sa politique d'utilisation que vous pouvez consulter en ligne.

https://apropos.erudit.org/fr/usagers/politique-dutilisation/ 


\section{Voltaire and 'Maman': Female Sexuality, Maternity and Incest in the Tragedies}

There is a wide range in Voltaire's writing with regard to the rôle and value of women in society, from the almost feminist tone of the preface to Alzire, in which he praises Mme de Châtelet's erudition, to the prevalence of women as pathetic victims in his theatre which Lucette Desvignes has discussed. ${ }^{1}$ Nonetheless Voltaire's theatre in eighteenthcentury performance is marked by productive working relationships between the author and the strong-willed, creative actresses of the period-Le Couvreur, Quinault, Clairon. These tragic heroines were clearly rewarding rôles at least in a performance sense, and were popular with audiences.

In this paper, I wish to discuss some of the major tragic heroines in terms of their social rôles-as daughters, wives, mothers-and to consider the causes (if any) of their sufferings. I will set forth the ambivalence expressed by this theatre towards female sexuality, the complex relationship between sexuality and maternity, and between these and the treatment of incest, an inter-relationship suggested and summarized in Voltaire's nickname for the niece with whom he had a sexual affair: 'maman.'

In his tragic oeuvre, female sexuality is treated as something to be feared and controlled, whether by external paternalistic authority or by internalization of the values and duties imposed by that authority. Such duties are frequently impossible or internally inconsistent, from which dilemmas Voltaire often draws his tragic plot. Death becomes the favourite resolution to the impossibility of living as a woman, when it is not the favoured punishment for conscious or unconscious crimes against those duties. The situations of incest in these plays highlight this strict code of behaviour, and the dangers of unrestrained sexuality in women to themselves and to society. 
When a female character expresses love, it is usually in terms of subservience to the beloved male. Zaïre tells Orosmane:

J'ai par dessus vous

Ce plaisir si flatteur.......

De tenir tout, seigneur, du bienfaiteur que j'aime. ${ }^{2}$

These terms 'seigneur' and 'bienfaiteur' are also used in situations where the female dependence is on a father figure, suggesting a blurred line between affection for a male parent and a male lover, as we will see in Les Guèbres.

The duty and love owed by a daughter to a father is spoken of in the same hierarchical terms. The relationship between mother and daughter is germane to only one tragic text, Olympie, in which the mother, Alexander's widow Statira, acts as a channel for absent paternal authority. Most often the daughter is considered only in terms of her struggle to reconcile two male systems of authority, paternal and marital; the mother is absent, null. Such is the case for Zaïre, Zulime, Alzire, Palmire, Aurélie, Aménaïde, Arzème and Irène.

The father's authority is unquestionable. Idamé describes the Chinese empire, an idealized society contrasted with Mongol brutality, as first 'fondé sur le droit paternel' and 'sur la foi d'hymen,' and then 'sur l'honneur, la justice, / Le respect des serments. ${ }^{3}$ Paternal authority appears not as a deplorable aspect of the ancien régime, but as a necessary component of the philosophes' ideal society. This submission of daughter to father is not weakened by years of separation: Zaïre first addresses her father as 'seigneur' (Jacobs; II.iii.292). To Alzire, filial duty extends beyond abandoning the pagan Zamore to marrying the brutal Gusman at her father's order:

Je sais ce qu'est un père, et quel est son pouvoir;

M'immoler quand il parle est mon premier devoir....

Mes yeux n'ont jusqu'ici rien vu que par vos yeux;

Mon coeur changé par vous abandonna ses dieux. ${ }^{4}$

Palmire, raised in the belief that Mahomet is her de facto father, obeys him as 'un dieu qui m'épouvante' (I.ii). The father's power extends from control over behaviour and sexuality (in marriage) to control over thought and belief. When Mahomet boasts, 'Votre coeur a-t-il pu, sans être épouvanté, / Avoir un sentiment que je n'ai pas dicté?' (III.iii), he is expressing no more than normal paternal influence over a daughter. She remains faithful or converts to a religion as her father does, as we 
saw in the cases of Zaire and Alzire. Thus we see repeated the association between paternal and divine authority over women.

No female character more vividly illustrates the absolute and compelling nature of paternal authority over a daughter than Electre. Her speeches centre on mourning Agamemnon, castigating her mother, and beseeching the heavens to send Oreste to avenge their father's murder. ${ }^{5}$ She never mentions Agamemnon's sacrifice of her sister Iphigénie. Furthermore, as the representative of her father's spirit crying out for vengeance, her own hands are clean of her mother's blood, and she suffers no retribution.

Only when that authority, whether of father or lover, has lost its legitimacy does the female character resist or argue. For example, Mahomet's power over Palmire is broken when she learns he is not her father, and she repulses him: 'Imposteur teint de sang, que j'abjure à jamais!' (V.ii).

Among these obedient daughters, Aménaïde in Tancrède is virtually unique in her independence. Reared by her mother and betrothed to Tancrède by her in their exile, Aménaïde has but late come under her father's control. She respects her father, but puts off obeying him in act I, scene iv. Later, Argive grants her an unparalleled concession: 'Ma fille, je n'ai plus d'autorité sur toi. / J'en avais abusé, je dois l'avoir perdue' (IV.vi). However, this self-determination is made the instrument of her own downfall in that it prevents her from explaining the misdirected letter either to her father or to Tancrède. Her silence becomes the cause of Tancrède's death.

When the daughter becomes a wife, the duties of marriage allow no exceptions, even if the marriage was against inclination or the husband brutal. Although Eriphile was married at sixteen without consultation or affection, her husband was a 'demi-dieu dont je fus la coupable moitié. ${ }^{6}$ Clytemnestre is made subordinate, no more than the 'première sujette' under Egisthe (Oreste I.v). Artémire, with an irrationally violent husband to whom she was married against her will after he killed her father, accepts that it is her duty to obey him, to take no action against him nor even to save herself from him (Artémire I.ii, II.i). The same theme of the virtuous wife's duty to her abusive husband is repeated in Voltaire's next play Mariamne, and at the end of his career in Irène.

Widowhood, however, is not in these plays the woman's emancipation from male authority. Statira withdraws to the seclusion of a temple; Mérope spends fifteen years in masterly inactivity, waiting for her son's return. There is no example of a concluded second marriage in these plays, not even between Clytemnestre and Egisthe. In this regard Voltaire draws his dramatic norms from the legal and social constraints put on widows by his society. In Abensour's analysis of the legal treatment 
of women in pre-revolutionary France, widows might have more freedom than wives but they were not men's equals, whether in terms of the right to control property, to remarry or to put off mourning (23-24). In this context, the rules by which Mérope and Statira live seem less arbitrary and unrealistic; Voltaire's contemporary audiences found these characters touching, not implausible.

Female sexuality, controlled by obedience to male authority, is shown to find its fulfillment in maternity, and particularly in the birth of a son. Good mothers channel their energies and ambitions into him, and sacrifice everything for him; the character of Mérope is a well-known example, as is that of Idamé. There are few legitimate outlets for female ambition and ability beyond sublimation into her children. Mérope, the daughter and the widow of kings, refuses to seek the throne for herself, which would seem an excellent way to ensure political stability. She is throughout the play solely concerned with finding her son and seeing him crowned. ${ }^{7}$

Even the capable and proud queens of myth and history like Clytemnestre and Sémiramis are shown as weak, dominated by their male accomplices, and miserable with remorse. Even to these, the relationship between mother and son is paramount. Clytemnestre welcomes Oreste's return though it means her death, even risking herself to protect him from Egisthe (III.vi, IV.viii). She promises in act V scene iii, 'J'obtiendrai sa grâce, en dussé-je périr,' a promise kept to the letter. Sémiramis is portrayed, somewhat implausibly, as turning to government not out of ambition but as a consolation for her unhappy marriage and the loss of her son to another oracle (III.i). Suppressed mother love is at the heart of her attraction for Arzace, and she dies forgiving him (V.viii).

Such authority as a mother has over child is most clearly seen in Olympie, where the father is dead and Statira is 'veuve d'un demi-dieu, fille de Darius' (II.ii). As an agent of male authority, she can command Olympie and expect compliance. Statira seeks to put her daughter under what she considers legitimate male control, that of Antigone. In a classic controlling gesture, she uses even her own death to tighten Antigone's claim: 'Elle m'aime, etj'ordonne / Que, pour venger sa mère, elle épouse Antigone' (IV.viii). Olympie, faced with Zaïre's dilemma between duty to parents and love, makes Zaïre's choice of filial loyalty at a cost of death.

In the face of this complex system of strict but overlapping and conflicting duties to various male authority figures, these female characters inevitably fail. They take blame, they are tormented by guilt, and they are punished. 
Blame, for our purposes, can be defined as the taking or accepting of responsibility for another's actions. Aurélie, who was unaware of Cataline's conspiracy, declares herself his guilty accomplice when she learns of it (Rome sauvée III.ii). Palmire, as unconscious as Aurélie of the true nature of the plot against Zopire, upon discovering the truth takes all responsibility for his murder by Seiide, exculpating even Mahomet (IV.v). Olympie makes herself guilty of Cassandre's crimes against her family committed before she met him (III.iii). Blame is seen thus as largely subjective and even retroactive, expressing a feeling of responsibility separate from any legal culpability, or even guilty knowledge.

Guilt, like blame, is internal rather than external, but it stems from conscious violation of one's duties. While remorse and repentance are sympathetic characteristics, they do not constitute extenuating factors. To Artémire and Mariamne, their inability to love the husband who threatens to kill them rather than the lover who offers them refuge is the crime for which they feel they must be punished (Artémire III.i, Hérode et Mariamne V.ii). Even Sémiramis, the ruthless and successful Assyrian queen, is painted as so devoured by remorse for her crimes that she is unable to govern: 'Succombant au mal qui la déchire, / Ses mains laissent flotter les rênes de l'empire' (I.i).

In none of Voltaire's tragedies, not even those with happy resolutions like Adélaïde du Guesclin, Alzire or L'Orphelin de la Chine, can we see a female character's free choice result in happiness. Many of these characters express the view that death is the only choice or decision they can make. Alzire, as an example, when torn between her love for Zamore and her duty to Gusman, exclaims, 'Qui me délivrera par un trépas heureux, / De la nécessité de vous trahir vous deux?' (III.vi, emphasis mine) Even those deaths which come as punishments are welcomed. Eriphile and Sémiramis ask for death at their sons' hands, in fulfillment of the prophecy and as the only expiation for their crimes. Zulime's suicide is explicitly made one of atonement for her crimes against her father (V.iii). These heroines know and accept that they deserve their end.

From the punishment of these characters comes the restoration of order under a male ruler. Realms in which female independence has been permitted fall inevitably into chaos and violence, whether Assyria under Sémiramis or Trébizonde under Zulime. A woman's authority, except as mother, is not legitimate. Mérope, as a good mother, refuses the throne even as régente for her son. Against well-known historical examples, Voltaire argues in these plays that females are not fit to govern and are not accepted as rulers by their subjects (e.g., in Eriphile I.iv). 
The restraints placed on the exercise of authority by women extend from the political realm to the sexual. We can find in the plays all three situations of incest: female-dominant, sibling, and male-dominant. The first two types result in punishment for those involved, and are spoken of with great loathing. Jocaste and Oedipe, Eriphile's attraction for Alcméon, and that of Sémiramis for Arzace are all of the female-dominant or mother/son pattern; Palmire and Séïde, Arzème and young Arzémon illustrate the sibling. The result of mother/son incest is well known. In Palmire's words, sibling attraction is 'un amour plein $\mathrm{d}^{\prime}$ horreurs' (Mahomet V.i). The third pattern, possibly because of the similarity between the power held by husbands and that of fathers over their female dependents, is not seen to be punished. Mahomet, in his brief attack of remorse, does not repent of his tendency to make foster daughters like Palmire into wives. Iradan in Les Guèbres, while happy to see Arzème with young Arzémon once he knows they are cousins, feels no guilt over his attempt to marry her, his niece. The mere revelation, however, of her unconsummated love for one she believes her brother revolts him (II.iii). We note that it is Iradan, and not her natural father, to whom Arzème turns for help, whom she calls 'bienfaiteur adoré' (V.ii). The parallel with Voltaire and Mme Denis is striking.

There are no cases of incest between a biological father and daughter, only between father-figures and dependent females. It is tempting to see a link between this figure and Voltaire, whose preference for playing wise father rôles on the amateur stage as in real life is well-known. Voltaire is careful to make clear that the incest in all cases is unconscious and except for Jocaste and Oedipe unconsummated. Eriphile is drawn to Alcméon by something more pure and tender than love, and by her rational distrust of Hermogide (II.iv). Arzace feels no attraction to Sémiramis, only respect; she insists, 'Ce n'est point l'amour qui m'entraîne vers lui' (III.i). Although bienséances limited the depiction of incest on stage, Voltaire is more restrained even than Racine or Crébillon in portraying instinctive affections which effortlessly become natural familial love on discovery of the blood relationship.

Yet despite this careful purity, the retaliation is as severe on those who transgress. A woman involved in an incestuous affection suffers; the men, with the exception of Oedipe, do not. ${ }^{8}$ The exception, one may argue, was forced on Voltaire by the familiarity of the myth. Arzace and Alcméon kill their unfaithful and potentially incestuous mothers under the same circumstances of misunderstanding as Oreste without pursuit from the Furies, further suggesting gender bias in the working of justice within the plays. 
While Desvignes has already indicated the clear pattern of martyrdom in Voltaire's heroines, she argues that it was a deliberate exaggeration of conditions in eighteenth-century France, by which Voltaire intended to evoke sympathy and possibly encourage change (550-51). One should weigh this conclusion against the observations of contemporary critics such as Collé who deplored Voltaire's excessive penchant for pathos and remorse in female characterization, and the enthusiastic frequency with which such heroines were parodied. ${ }^{9}$ We note that when criticizing other aspects of French society, Voltaire offered positive models as well as negative; he set out what a king, a father, a priest should be. But he did not seem to offer alternatives to the social subservience of women. There appear to be no heroines within these plays who succeed in escaping that captivity to duty without suffering retribution. There is not even a consistent reward for virtue within his tragic universe: under similar circumstances Zaïre is killed but Alzire lives, Mariamne dies and Artémire survives. Incest which violates the codes of maternal or filial duty is the most extreme state of non-conformity to the constraints of society on female sexuality. Even when Voltaire's text is clear that the incest is neither conscious nor consummated, the mere attraction draws the strongest condemnation on the woman involved.

And so we return to our original hypothesis, that female sexuality is a dangerous force which paternalistic authority must restrain. The only way within the microcosmic world of these plays for a woman to keep her obligations, to be safe within and to society is by her retreat into death. While Voltaire's female characters offered excellent rôles to eighteenth-century actresses in the eloquent pathos of their helpless suffering, their attractiveness as rôle models is dubious. As Mariamne expresses the lesson. a woman's glory lies in knowing how to suffer (V.iii). These tragedies remain within strongly patriarchal norms of social and familial structure. The 'good father', a favourite theme of Voltaire's, ${ }^{10}$ appears as a benevolent despot in a social system where not even freedom of belief is extended to women. They are objects or victims, consistently rendered passive, a process which leads inevitably to the resolution of 'female' problems in death.

HOPE M. LEITH

University of British Columbia 


\section{Notes}

1 Lucette Desvignes, 'Le Théâtre de Voltaire et la femme victime,' Revue des sciences humaines 44 (1977): 535-551. On feminist elements in Voltaire's work, see also Maïté Albistur and Daniel Armogathe, Histoire du féminisme français du moyen âge à nos jours (Paris: Editions de femmes, 1978) 191-92; see further Léon Abensour, La Femme et le féminisme avant la révolution (Paris: Ernest Leroux, 1928) 361ff for a discussion of the philosophes' views on women. The research presented in this paper represents an early and partial version of an analysis of the social ideology of Voltaire's tragedies that will constitute chapter 3 of my forthcoming doctoral dissertation.

2 Zaïre, ed. Eva Jacobs, Complete Works of Voltaire 8 (Oxford: Voltaire Foundation, 1988): 273-526 (I.i).

3 L'Orphelin de la Chine, Oeuvres complètes de Voltaire, ed. Louis Moland et al. (Paris: Garnier, 1877) 5: 291-360 (IV.iv).

4 Alzire, ed. T. E. D. Braun, Complete Works 14 (Oxford: Voltaire Foundation, 1989): 1-210 (I.iv.251-52, 255-56).

5 Oreste, Moland ed. 5: 71-165 (I.ii, II.vii, III.iv).

6 Eriphile, Moland ed. 2: 453-530 (I.iii); I follow Robert Niklaus in adopting Voltaire's own spelling of 'Eriphile': see 'Eriphile de Voltaire et le théâtre d'Eschyle,' Le Siècle de Voltaire: Hommage à René Pommeau, ed. Christiane Mervaud and Sylvain Menant (Oxford: Voltaire Foundation, 1987) 2: 707-18.

7 Mérope, ed. Jack R. Vrooman and Janet Godden, Complete Works 17 (Oxford: Voltaire Foundation, 1991): 91-387; see her speeches in I.i, II.i and III.ii.

8 Séide's death, while engineered by Mahomet, is morally justified to the audience and to himself by his parricide and not his attraction to Palmire (see V.iv).

9 Charles Collé, Journal et mémoires, ed. Honoré Bonhomme (Paris: Firmin Didot, 1868) 3: 236. The Moland editions of Hérode et Mariamne, Sémiramis and Tancrède list the parodies made of each.

10 Haydn Mason, 'Fathers Good and Bad in Voltaire's Mahomet,' Myth and Its Making in the French Theatre (Cambridge: Cambridge UP, 1988) 121-35. 